\title{
The Origins of Padang Cuisine and an Economic Impact of Minangkabau Peoples in Surabaya (1960's -owadays)
}

\author{
Corry Liana ${ }^{1}{ }^{*}$ Wisnu ${ }^{2}$, Eko S. Hermawan ${ }^{3}$ \\ ${ }^{1,2,3}$ Universitas Negeri Surabaya \\ *Corresponding author. Email: corryliana@unesa.ac.id
}

\begin{abstract}
Minang society is one of the ethnic groups in Indonesia that has a tradition called merantau (migrating). They migrated to foreign countries, which are specifically based on Malay culture. One of them is Malaysia (and Singapore), also known as Melaka. Meanwhile, Surabaya is not the wandering destination for minang society. However, it is currently experiencing extraordinary development. One of the characteristics of the presence of Minang society is "rumah makan padang". This restaurant became a driving force for the economy. This study aims to examine more of the history and development of minang society in terms of migration from an economic aspect. Through a historical approach using perspective migration theory by De Jong, the study reveals how Padang restaurant became the cultural capital of minang society overseas. This study uses a qualitative approach with data collection techniques in the form of interviews or oral history. The results obtained show that the migration of minang society in Surabaya is based on the purposive behavior of perspective migrants, who consciously make decisions by feeling consequential and evaluative. The results of feeling and evaluating the migration area resulted in the decision to build the Padang restaurant as a livelihood in Surabaya. In terms of income, Padang restaurant that managed by minang people, generates a large income, it can be seen from the employees and how they send money to their hometown.
\end{abstract}

Keywords: Migration, Minangkabau, Padang cuisine

\section{INTRODUCTION}

Migration is a choice made by an individual, community, or society to leave their hometown for the destination area. Everett S. Lee said in his theory about migration that it is an attempt to survive or to make a better life when the territory of the origin town (hometown) where they live is not supported. It seems that this has become a part of Minangkabau society's thinking in Indonesia. Leaving their hometown of Minangkabau (West Sumatra) and migrating to all corners of the country, even though it should have passed the country's administrative boundaries, seemed like a choice to become the goal for a better and more dignified life.[1]

In the records of Indonesian history, the Minangkabau community made the largest contribution to the independence of Indonesia. A number of the father figures of Indonesian nation came from Minangkabau. Minangkabau's society is educated and has a large cultural capital. They migrated to Batavia and Leiden to pursue higher education, like: Mohammad Hatta, Mohammad Yamin, Moch Roem, and Tan Malaka. These Sumatran famous figures are experts in diplomacy, economy, and constitutional law. Literacy traditions have become part of their cultures. People will know the names of a number of great writers from the preindependence era, like Sutan Takdir Alisyahbana and Marah Rusli. Meanwhile, during Suharto's reign, a number of outstanding ministers came from the Minangkabau tribe, such as Emil Salim and Anwar Anas.[2], [3].

On the other side, which escaped the attention of the greatness of Minangkabau society in Indonesia, is the Padang restaurant, also known as masakan Padang. This culinary industry has penetrated throughout the country, even Southeast Asia. In Malaysia, Singapura, Thailand and Brunei Darussalam, the Padang restaurant exists as one of the food stalls. The famous dish and become the mainstay menu in Padang restaurant called Rendang. It is a dish of beef pieces stewed in chili and coconut milk, kept on the fire until the liquid has completely evaporated and oily. Rendang has been nominated as one of the most delicious foods in the world [4]

On the other hand, Padang restaurants have been involved in a modern management system by developing a franchise, such as "Padang sederhana" restaurant. On its website, this restaurant has been established since 1972 in the Bendungan hilir area, Jakarta. Then the founder established the company known as PT SCM (Sederhana Citra Mandiri) and attracted investors to build a restaurant along the Surabaya-Jakarta road. The development patterns for the 
restaurant Sederhana have also been carried out for the other restaurants. They standardize the food and the way it is served. Therefore, some studies about Minangkabau communities have focused on Padang restaurants rather than their communities [5].

One of the studies about Padang restaurant in Jakarta was carried out by Andriyanti, et.al (2020). The research team observed that the owner of Padang Restaurant carries out supply chain management with trusted a supplier. In addition, together with the government, they seek ease of licensing, halal products, health, food safety, financing, and food security, as well as food technology and digital promotion. The same research was also reviewed by Rosalina, et.al (2015). This promotion and marketing are needed because Padang restaurants have to deal with a negative stigma that contains cholesterol and its risk for heart disease [7]-[9].

Apart from health problems in Padang cuisine, Padang restaurants with their various variants have become a marker of the presence of the Minangkabau ethnic group in the overseas area, as well as in Surabaya. However, there is no specific study about the establishment of Padang cuisine restaurants in Surabaya. From the perspective of multiculturalism identity, the Padang cuisine serves not only as the Minangkabau ethnic group's identity but also as a bridge for other ethnic groups to recognize and accept the presence of the Minangkabau ethnic group. This is not considered in Mila's research (2019). The study which has been discussed by Mila focused on the migration history of Minangkabau Society, the formation of Minangkabau community, and the establishment of rumah gadang (known as "big house"). The Minangkabau community is united into Gebu Minang (Gerakan Seribu Minangkabau) also known as thousand Minangkabau Movement 10].

\section{METHODS}

This study uses a qualitative approach with data collection techniques in the form of interviews or oral history. The data analysis of qualitative research was carried out according to Wolcott, who suggested three aspects of data analysis, namely, descriptive, analysis, and interpretation. First, describe in detail and comprehensively all collected data; second, do analysis with inductivedeductive logic; third, interpret in the sense of carrying out the interpretations of what is contained behind the analyzed data.[11] The data was collected using the snowball technique (it was like a snowball, which was initially small, but gradually grew larger). Thus, data collections are dynamic. Which means that each collected data set is continuously criticized and developed in accordance with the research interest until the data is complete (Spradley, 1997). [12]. The data collection was carried out using in-depth interview techniques.

The in-depth interview technique uses open-ended questions, making it easier to develop further questions.
Interviews were carried out by going directly or face to face with the informants, either at home or at work in accordance with the agreement, which had been mutually agreed upon.

\section{RESULTS AND DISCUSSION}

De Jong dan Fawcett (1981) applied the valueexpectancy model of migration, which argues that the migration motivation depends on the sum of the expectancyvalue product; that is, the motivation to migrate is influenced by the expectation that the move will fulfill certain personally worthwhile goals. Individual decisions to migrate are influenced by a complex problem, macro flows may be easy to predict with several economic indices from various regions. In the end, all these complex individual decisions tend to cause mass displacement from areas of less economic opportunity to the areas with better economic opportunity. The main value dimensions of individuals associated with migration have been identified by De Jong and Fawcett, which consist of prosperity, status, comfort, stimulation, affiliation, and morality.

\subsection{Prosperity}

The Minang families who migrated to Surabaya have a fairly prosperous level of prosperity. These levels of prosperities include (1) obtaining a high income, (2) having a steady income, (3) getting economic security in old age, (4) being able to produce basic needs; other stuffs and (5) obtaining social insurance and other economic benefits. Regularly, Minang society in Surabaya sends monthly money to their hometown, that money is used to buy land or repair houses. Mr. Dicky Darjo, the owner of Ampera Danai restaurant explained that,

"I send money to my hometown of Bukittinggi every month, the amount is not too much, adjusted with my monthly income. If I do not send money, I am ashamed of my family."

The main motivation of Minang society merantau (migration) is all about money, same as like what Amir B said in Ermansyah, who explains that migrating as an activity of leaving one's hometown to get a better life. It is in accordance with Minang philosophy hilang rano dek panyakik, hilang bangso dek indak barameh (lost color due to disease, lost nation due to no wealth). Minang society is always trying to plan for their future and what will be left after death. Mancaliak nan ka sudah (looking at what has been passed) is a Minang philosophy which explains that there must be a legacy (treasure).

\subsection{Status}

People who have high social status will be placed higher in the community structure compared with people with low social status. According to Garden, the difference in status is after households in their hometown: (1) getting an authoritative job, (2) being respected in the society, (3) getting a good education, (4) having power and influence. Minang people who have wealth will automatically have a 
high social status. In the Minangkabau tradition, migration is believed to have arisen because of the matrilineal system, which only gives inheritance rights to women while men only have small rights. Minang men have the motivation to migrate in order to have abundant prosperity so that their social status also increases.

\subsection{Convenience}

Comfort is defined as pleasure, freedom from pain, need, anxiety, or anything related to something unpleasant that exists in the family's origin area (hometown). This feeling of comfort is more about the matrilineal system that exists in Minang society. Asrul Nan Bungsu explained that:

Those of you who are Javanese, do not worry about money problems because there must be an inheritance. We, as men in Minangkabau have to work hard because we won't receive an inheritance, that is why we decided to merantau (migrating). It is not good to live without owning something (treasure).

The discomfort felt by Minang men becomes a motivation for them to migrate. Mr. Asrul has been emigrating since 1983 in order to find prosperity and comfort. He migrated to Jakarta, Bandung and in 2008, decided to stay in Surabaya and opened the Muara Padang restaurant on Jl. Raya Perak.

\subsection{Stimulation}

Stimulation is stimulus that comes from the environment outside of the individual. Minangkabau itself has the value of local wisdom about the recommendation to go abroad, try their luck, and then return home to bring success. The results and efforts to implement the culture of wandering can be used as customs, norms, and cultural values to be maintained, respected, and developed from generation to generation. So it is not surprising that the Minangkabau people spread to almost all regions in Indonesia. These values and local wisdom are what made minang people migrate. Because, most of their families have become successful in overseas areas. Mrs Mimi Hardini migrated with her parents in 1999 from Pariaman, they decided to migrate because Mrs Mimi's father has an uncle who has a padang restaurant business in Surabaya.

The family or relative's success who migrate to all regions in Indonesia has become a strong stimulus for minang community to merantau (migrate). Surabaya is not a favorite area for Minang people to migrate to, but in Surabaya there are minang community associations that have good work programs also. A thousand minang movement or gebu minang institute for East Java region, is an association of minang people in Surabaya. Over time, the abbreviation of Gebu Minang was changed to the minang economic and cultural movement, but still in the abbreviated format Gebu minang. In accordance with these changes, this foundation specifically takes part in the economic and cultural fields, and becomes a stimulus to minang people to come and migrate to Surabaya.

\subsection{Autonomy}

Autonomy is a society or individual who has the right and authority to self-regulate, and be responsible without outside intervention. There are six Minangkabau principles that are traditionally considered to apply in the society, which are:

1. Those who give birth and those who have children are women (mother or known as Mande).

2. Those who have authority and power over women and children are men.

3. Descendants are drawn and traced through the female line (matrilineal).

4. The female line is used to appoint or recruit members of descendant groups (suku (tribe) payuang (umbrella), paruik (stomach), kampuang (homwtown) and rumah gadang (big house)).

5. The inheritance, rumah gadang (big house), titles, positions, and political power are carried out through the female line.

6. Exogamous group marriage (tribal exogamy, payuang (umbrella), or paruik (stomach)) is a must.

7. On the other hand, the endogamous marriage (tribal endogamy, payuang (umbrella) or paruik (stomach)) is incest taboo.

These six customary principles are the reasons why minang men decide to migrate. By migrating, minang men have the freedom or autonomy in making decisions, especially those to whom they are married.

\subsection{Affiliation and morality}

An affiliate refers to joining, bonding, or as an expected bond. While morality is the absence of thinking and acting, it is based on the character and values that exist in the area of origin (hometown) regarding the purpose of the value of hope after one or more of the activities have migrated. Minang proverb says "Karatau tumbuah dihulu, babuah babungo alun, marantau bujang dahulu, dirumah baguno alun". This proverb emphasizes that boys who are single or unmarried do not have a role or position in adat. This is because children are considered to have no experience, therefore, they must seek experience by going abroad.

There are parents who force their teenagers to leave their hometown to merantau (migrate) as far as possible from their hometown, Minangkabau, because there is a belief that the farther the overseas location is, the more life experience they will get. So that when they return, they will be more useful and wiser to society and can contribute their thinking and experience to running either their family or hometown. The ties and values that exist in minang society are one of the motivations why minang people decide to merantau (migrating). 


\section{CONCLUSION}

Based on the findings, discussions and analysis of the two main subjects, which are: the migration patterns and also the economic growth of the minang community in Surabaya, it was found that migrations were influenced by seven factors: prosperity, status, comfort, stimulation, autonomy, affiliation and morality. These seven factors can be achieved when minang people, especially men, decide to migrate. Of 10 respondents who have been studied, 7 of them own Padang restaurant, which has class B and A consumers and already has more than 1 branch. This shows that the economic development of the minang community in Surabaya is growing rapidly, especially for those who have a Padang restaurant business.

\section{REFERENCES}

[1] Audebert and M. K. Doraï, "Migration in a Globalised World," in Migration in a Globalised World. New Research Issues and Prospects edited, 1st ed., C. Audebert and M. K. ". Dora1, Eds. Amsterdam: IMISCOE Research. Amsterdam University Press, 2010, pp. 7-21.

[2] M. C. Ricklefs, A History of Modern Indonesia since c. 1200, 4th ed. Hampshire: Palgrave Macmillan, 2008.

[3] R. Schulze, Official History in Modern Indonesia. 2005.

[4] P. E. de Josselin de Jong, Minangkabau and Negri Sembilan. Dordrecht: Springer Netherlands, 1980.

[5] A. Yulastri, "Pengembangan Rumah Makan Masakan Padang Dalam Menuju Perlindungan Hak Kekayaan Intelektual (hki," presented at the Seminar dan Lokakarya Perlindungan Hak Kekayaan Intelektual (HKI) Rumah Makan Padang, Padang, 2008.

[6] R. Andriyanty, M. Aras, S. N. Afuani, and A. Nurfallah, "Strategi Pengembangan Bisnis Rumah Makan Padang Di Sekitar Lingkar Kampus Ibi Kosgoro 1957," Mediastama, vol. 26, no. 1, p. 22, 2020.

[7] E. Rosalina, A. Wirahadi Ahmad, and A. Dwi Haryadi, "Strategi Pengembangan Makanan Unggulan Minangkabau Berdaya Saing Global," JAM, vol. 10, no. 2, pp. 41-50, Dec. 2015, doi: 10.30630/jam.v10i2.104.

[8] N. A. Rahmi, M. Z. Rahffudin, and D. R. Pangestuti, "Hubungan Kebiasaan Konsumsi Masakan Padang dengan Kadar Kolesterol. (Studi pada Paguyuban Ikatan Mahasiswa Minang Angkatan 2015 di Semarang)," Jurnal Kesehatan Masyarakat, vol. 5, no. 4, 2017.

[9] Helmizar, F. Jalal, and I. Liputo, "Antioksidan dalam Masakan Minang dan Potensi Protektif thp Risiko Penyakit Kardiovaskuler," Jurnal Kesehatan
Masyarakat, vol. 4, no. 1, 2010.

[10] Mila, "Komunitas Minangkabau di Surabaya. Studi Perubahan Tata Cara Perkawinan Minangkabau," Skripsi, Fakultas Adab dan Humaniora. Universitas Islam Negeri Sunan Ampel, Surabaya, 2019.

[11] E. S. Lee, "A Theory of Migration," Demography, vol. 3, no. 1, Art. no. 1, 1966.

[12] Artono, Komunitas Arab di Kota Surabaya 1900-1942. Yogyakarta: Kendi, 2021.

[13] G. F. De Jong and J. T. Fawcett, "Motivations for Migration: An Assessment and a Value-Expectancy Research Model," in Migration decision making: multidisciplinary approaches to microlevel studies in developed and developing countries, G. F. De Jong and R. W. Gardner, Eds. New York: Pergamon Press, 1981.

[14] A. Na'im and H. Syaputra, Kewarganegaraan, Suku Bangsa, Agama, Dan Bahasa Sehari-Hari Penduduk Indonesia. Hasil Sensus Penduduk 2010. Jakarta: Biro Pusat Statistik Indonesia, 2011.

[15] A. Murad, "Merantau: Aspects of Outmigration of the Minangkabau People," Thesis, Australian National University, Canberra, 1978.

[16] M. Naim, "Besarnya migrasi Sukubangsa Minangkabau dan Sukubangsa-sukubangsa Lain di Indonesia: Beberapa Perkiraan Statistik," in Masalahmasalah Pembangunan. Bunga Rampai Antropologi Terapan, Koentjaraningrat, Ed. Jakarta: LP3ES, 1982. 